\title{
Between Ethics and Desire: The 'Torment' of Becoming Parent in the Everyday Life of Intercountry Adoptive Families in Italy
}

\author{
Rossana DiSilvio
}

\author{
University of Milano-Bicocca \\ E-mail:r.disilvio@campus.unimib.it
}

Doi:10.5901/ajis.2013.v2n8p280

\section{Abstract}

The domestic domain is considered to be, because of its own nature, the favoured realm of the ethics expression in everyday relationships. This rooted vision seems to concern the relations between parents and children in particular. But what happens when the parenting relation is lived an practiced with strangers? As many social studies highlighted, during the last three decades a wide diffusion of intercountry adoptions occurred in Western countries, where the adoptive family is established by law as being on the same level as the biological family. Italy is considered one of the Western countries with the highest number of arrivals of adopted children, in a social scenario marked by a deep transformation of the domestic domain. Based on a two years' ethnographic research on Italian adoptive families, my paper aims at highlighting a particular ethical side of the process of adoptive kinning, which is often not investigated in detail. In fact, on the one hand infertile couples seem to be particularly sensitive towards the rhetoric of international discourses as well as of the media iconography, which solicit that ethical personal responsibility necessary to take care of a child considered to be unlucky because 'orphan', ill and born in the so-called Third or Second World. On the other hand, the concrete action of 'taking the child, bringing him/her away' and removing all his/her previous ties (as established by international adoptive devices), seems to urge new parents 'to perceive themselves as thieves', as someone stealing the child from his/her family and country of origin. The effects of this double-sided ethics act deeply in the everyday life of adoptive families, particularly in the process of internal legitimation, whose outcome is crucial for the success of a "good" adoptive parenting.

Keywords: family; intercountry adoption; ethnography; parenting; care; stealing; double-sided ethics;

\section{A globalized social event}

Intercountry adoption has become a very wide social phenomenon in many Western countries during the last three decades, and it stimulated a great interest in the anthropological studies, particularly toward the studying of new forms of kinship in the contemporary world (e.g. Volkman, 2005; Howell, 2007; DiSilvio, 2008; Yngvesson, 2010). Indeed, intercountry adoption clearly takes the shape of a globalized event, especially from the 1990's when a high number of 'orphaned' children were moved from many countries of the so-called Third or Second World to the well-heeled countries of the First World.

Some scholars have spoken of a 'silent migration' (e.g. Lovelock, 2000; Selman, 2002) and someone else of a 'neo-colonial abduction' (Hubinette, 2004), like the slavery trade of the 18th century. Although these visions might appear too drastic at a first glance, they certainly arise from some proved facts, tightly related to each other.

Many demographic studies highlighted how intercountry adoption moved little less than 50 thousand children per year to Western countries during the last 30 years (Selman, 2006). Italy, where I conducted my research, ranks among the most active countries in the reception of intercountry adoptees (DiSilvio, 2008, 2010c, 2012). Public institutions, such as the Commission of the International Adoption (CAl), claim that in the last 20 years the number of adopted children who entered the country was around 5 thousand per year, more than half of whom were destined to the richer Northern regions (CAI, 2011). In addition, unlike what happened in many other Western countries, in Italy adoptees' relocations did not recently drop (Selman, 2009), demonstrating all the strength of this phenomenon within the Italian social scenario.

Historically, these children have been usually coming from Asia - especially India, but lately also from China and Vietnam -, South American countries - Brazil, Colombia, Peru, Guatemala, Honduras - and, after the fall of Soviet Republics, a really high number of children came from Eastern Europe, particularly from Ukraine, Russia, Romania. 


\section{Hegemonic practices}

All the so-called 'donor countries' had to subscribe to the international devices and norms on intercountry adoption according to which, differently from traditional practices, children circulation requires a clean cut (the so called 'clean break') with both the birth family and the country of origin (Duncan, 1993).

Maybe we cannot define this movement just as a 'migration' process because the main actor involved, that is the 'orphaned' child, is not assumed to be somebody who can choose his future as migrant, but what happens is that the country of origin, as his legal tutor, takes the decision in his stead. Of course, it never is a free choice. Many dynamics are in action, or rather, many are the power exercises acting in the field of the globalized intercountry adoption (Bourdieu, 1992).

The events that occurred in Romania just after the Ceausescu fall may be a clarifying example. Defense for Children International (1991), an organization linked to UNICEF, supposed that from March 1990 until June 1991 little less than 15,000 children were moved from Romanian orphanages to 22 Western countries without any legal displacement ratified by the government of the country of origin. Of course, this happened in the name of 'the best interest for the child' (Goldstein et al., 1979) because, within Western houses, the survival conditions of children in Romania were considered to be on the borderline. But when, in a distressing landscape full of social and economic problems, that children flow was finally interrupted, the new Romanian government had to cope with the children protection measures requested by the EU, obviously in return for the EU economic support. Of course the new Romanian government was not able to immediately comply with the above mentioned EU children protection measures. The solution was to give the children up for adoption to European or American couples.

This happened several years ago, of course, but it is not so far away from what occurred during the Darfur crisis or the Haiti earthquake, as media widely reported (e.g. Crumley, 2007; Westcott, 2010). So, it is not always the case, but unfortunately many times the adoptive kinship takes its first steps in a nebulous scenario where a complex experience of the private is thrown into the heart of hegemonic exercises of power (economical as well as political powers).

\section{Desires and bodies}

However, as I could observe, the aspiring parents, or the new-parents as well, seem not to know or to be unaware of the underhanded and slippery ground on which they move. Indeed, at the beginning of their path, many of the Italian adoptive parents appear to be much more involved and caught by two main frames of mind : the moral duty to save a 'orphaned and poor' child from his tragic destiny and the desire to take care of him as if he was his own son. Their goal is to satisfy both these feelings, which meet their historically and culturally established representations of infancy, parenting and family.

Italian adoptive parents share these visions with both the Western dispositions in general and with a specific habitus (Bourdieu, 2003), culturally produced, in which the ideological power of the (Catholic) Church (Foucault, 2005) as well as of the familistic society is still deeply active, despite the changes of the domestic realm brought about by a birth rate among the lowest in Europe.

So, the media representations of the children's suffering bodies act in concert with the intimate need of the physical presence of a child in the infertile couple, because there is no family without the reality and visibility of the 'body' of the son.

Starting from this unequal exercise of power on bodies and desires, recently some scholars critically defined the Western intercountry adoption devices as a hegemonic strategy, historically produced, to pillage economically weaker countries for satisfying the desires of Western peoples (Hubinette, 2006). Like in the slavery trade, where bodies of 'Others' were forcedly displaced to answer the need of bodies-work, within the Western adoption practice children are 'abducted' to fulfill the desire of infertile couples, who want the body of a son to take care of in order to 'make' a complete family. In any case, what is now evident is the growing criticism on a system so open to abuse (Trisielotis, 2000; Fonseca, 2002; Smolin, 2007), founded on the gross inequalities still reigning in the planet, so that intercountry adoption devices may be labeled as a 'neo-colonialist mistake' (Parker, 2008:293). But the overgeneralization of a scenario, although it is deeply dark in many sides, may hurt most of the couples approaching the intercountry adoption full of hopes and with a clear behavior.

The Italian path to intercountry adoption is very hard for all those infertile couples who decide to adopt a son. Public institutions as well as social workers pay close attention to authorizing the Italian adoption agencies which work abroad, but they also put a lot of effort into training the aspiring parents. A great discursive emphasis is given to the ethic 
facets of the adoptive choice, mainly because of the personal suffering that children bring inside due to their lived experience. So, parents must attend several meetings with psychologists, judges and physicians to demonstrate to be able to handle the complex familiar experience in which they will live. Many trials have to be passed to be included into the social category of 'good parents' on which the true family is founded (Bourdieu, 1996). Only from that moment onwards, the couple can be legally legitimated in its 'social' parenting, which is established to be mimetic to the biological parenting.

\title{
4. Choices, ethics and torment
}

I met Simona, an adoptive mother, in 2007 during my fieldwork with Italian adoptive families. Few years before she and her husband adopted two children, the elder from Brazil and the younger from Ethiopia. Since a short while ago, she has also been the director of an adoptive agency which operates in Ethiopia and where she had been working as a volunteer for long. One day, while we were talking about her new commitment, she suddenly said:

\begin{abstract}
You know? While we were waiting for the suitability for our second adoption, I went to India as a volunteer for my association, to do something for those children involved in the program of remote adoptions. Well, I came back with the idea that I no longer wanted to adopt a child because, and I'm still persuaded, I think it is not right, it is not natural to bring a child away from his country .... it really seemed to me to go there and bring something away, steal something, steal the future of that country ... because Eastern countries are so, Eastern countries are impoverished, they are completely drained .... like Vietnam, too, and Cambodia, and India ... it is the same thing, they all have drained their future ... yes, then I adopted in Ethiopia, but there has always been this nag, this torment ...
\end{abstract}

So, I asked Simona why they adopted and she told me that the elder son lived in Brazil on the street having a carton box as a home, and the younger was so hardly diseased that he would surely die in those living conditions. In reality, both of them would die. And she and her husband couldn't do anything more than what they did. Because they had to cope with their children's conditions, it was not possible for them to think about all children or their country of origin as a whole, but they could only take care of that specific child and his unequal life.

In some way, it seemed that the 'torment' of Simona arose from the gap between two ethic dispositions that, in the case of intercountry adoption, display themselves and work in explicit opposition. The supposed action of a double-sided ethics in adoptive kinning, as Simona explained so clearly, became an interesting matter to deepen and study with a more detailed scouting. Particularly, my attention was drawn to the possible effects of the action of the 'torment' symbolic metaphor on the everyday life of the adoptive family and its members.

However, at a first glance, not all the adoptive parents I met seemed to show such an evident reflexive ability, as Simona did. During my ethnographic research, nobody talked about something similar to a 'torment' in their choice, but they only seemed to be very happy to have their child at home after having waited for so long. And for a while I thought that many of them had not had the lived experience of Simona, who visited the children's country of origin as a volunteer worker and thus developed a point of view besides the one of an aspiring parent.

As I said, in Italy perspective parents must face a long path of apprenticeship to reach what the social workers consider to be a satisfying ability in producing the meaning of familiar belonging under un-ordinary conditions (DiSilvio, 2010a). Because the ties between parents and children are not blood-founded, the adoptive family's members need to reshape their interior recognition in a different way (DiSilvio, 2010b).

Usually, the sharing of a substance (the blood or the genetic code and, as a consequence, an assumed physical likeness) legitimates a family in its social relationship life as well as in the interior representations and perceptions of the private family relationships conceived by its members (parents and children). But in the case of adoption, particularly transnational, things work in a different way.

\section{Double-sided ethics and family relationships: a poisoned perspective?}

We may say that the juridical norm establishes the public and external legitimation of the adoptive family in the social scenario, making it mimetically similar to the biological family. As regards the interior side, however, the matter appears to be much more complex. The new parents, and also the relatives, are embedded in the action of the habitus (Krais and Gebauer, 2009) to which they belong: this habitus claims the hegemony of blood ties in the production of the sole 'true' family.

Many scholars have understood the sense of alienation that seems to be permeating the adoptive kinning as an 
effect of the actions of the embedded blood hegemonic dispositions in the everyday life of the family ( Modell, 1994; Yngvesson and Mahoney, 2000; DiSilvio 2010b; DiSilvio, 2012). But I argue that, beyond the actions and effects of a familistic habitus, the presence of an unsaid ethical 'torment' emerges as an unwelcome ghost within the discourses and practices of the new parents and it works deeply for the construction of the meaning to be assigned to their private experience as an adoptive family. Indeed it may be very hard to build and manage an adoptive parenting care when the relationships between the receiving and donor countries as well as between the adoptive and birth parents are perceived as unequal in origin.

So, the mystifying rhetoric of the 'gift', widely shared in the official discourses on intercountry adoption (Ynvegsson, 2002; Solstad, 2005), was replaced by the gratitude an adoptive mother (but not the only) was feeling towards the unknown birth mother of her son/daughter, because in this way she had the impression to compensate for 'something wrong' that had happened through the adoptive displacement, although she was not able to precisely explain what 'something wrong' meant. On the other side, some parents seem to be really pressed by a sort of fear towards both the birth parents or relatives and the country of origin. They often suspect that the displacement system of their son/daughter can be tricky, so that they are not totally sure of the openness of the procedure.

The idea that someone belonging to the birth family might assert their rights on the allocated child, while adoptive parents are involved in the legal proceeding of adoption, is very widespread and also continues when adoptive parents are back in Italy with their child. Another common belief is that one day the country of origin might call the young adoptee back to army, as it happened for parents who adopted a son in Russia (which requires the twin-nationality until the son is 18 old). This is not possible and, of course, all these events do not take place, but these beliefs are present into the adoptive parents' discourses and representations of what kind of family they might face.

The two different feelings of compensation and fear seem to be the two sides of the same coin, and both these feelings are saying something about the lack of legitimacy perceived by the adoptive parents established through a thin ethical frame. In a domain, like the domestic one, where the doxa locates the specificity of unselfish ties, adoptive parents feel themselves as not fully authorized to be what they would wish to be, because the desired child, a 'gift come from heaven', may turn into a 'deceptive gift' in a short time.

\section{In sum}

When the gap between the representation of the 'free of charge' child, rhetorically instituted at the beginning of the adoption process, and the idealization of the gift, originating from the adoptee's arrival, is too broad, the perspective family experiences a 'split' in its effort to become a 'rue' family.

Unfortunately, lately it is not so rare that the new parents go to the public institutions, which established themselves as adoptive parents, to 'give back' the adopted child. So, I finally argue that some of the dramatic epilogues as well as the sense of alienation permeating the adoptive families' everyday life in Italy can be linked to the conflicting action of the embedded familistic habitus, the correlated hegemonic meaning of kinship blood ties and the ethical gap between the discourses on the child 'given as a gift' and the reality of the practices and the proceedings of the adoptive displacements in the globalized world.

\section{References}

Bourdieu, P. (2003). Per una teoria della pratica. Milano: Cortina Editore.

Bourdieu, P. (1996). On the Family as a Realized Category. Theory, Culture \& Society, 13, 12-26.

Bourdieu, P. (1992). Risposte. Per un'antropologia riflessiva. Torino: Bollati Boringhieri.

CAI (2012). Statistic Reports 2000-2011. http://www.commissioneadozioni.it. Viewed 25/2/2012.

Crumley, B. (2007). Charges Made in Darfur 'Adoption'. Time, 29/10/2007. http://www.time.com/time/world/article/ 0,8599,1677231,00.html. Viewed 20/12/2011.

Defense for International Children (1991). Romania. The Adoption of the Romanian Children by foreigners. Geneva: DCI/ISS.

DiSilvio, R. (2008). Parentele di confine. La pratica adottiva tra desiderio locale e mondo globale. Verona: Ombre Corte.

DiSilvio, R. (2010a), 'Almost the same, but not quite'. Fight between nature and culture in Italian adoptive rules and devices. Conference Paper. Paris: FSMH. Online: http://unimib.academia.edu/RossanaDiSilvio/Papers/30552

DiSilvio, R.. (2010b). The 'truth that can be told'. Re-writing broken identities to inventing a 'true' family tale in transnational adoption. Conference paper. Leiden: ICAR3. Online: http://unimib.academia.edu/RossanaDiSilvio/Papers/319389.

DiSilvio, R. (2010c). From Mother to Mothering. Ideologie, discorsi e pratiche attorno al femminile nello sguardo dell'antropologia 
culturale. Pedagogika, XIV, 40-57.

DiSilvio, R. (2012). Genitori del 'come se': le associazioni di famiglie adottive tra marginalità, legittimazione e appartenenza. In Koensler, A. \& Rossi, A. (Eds.), Comprendere il dissenso. Etnografia e antropologia dei movimenti sociali (pp.121-132). Perugia: Morlacchi Duncan, W. (1993). Regulating Intercountry Adoption: an International Perspective. In Bainham, A. \& and Pearl, D. (Eds.). Frontiers of Family Law (pp. 46-61). London: Chancery Law Publishing.

Fonseca, C. (2002). The Politics of Adoption: Child Rights in the Brazilian Setting. Law \& Society, 24, 199-227.

Foucault, M. (2005). Sicurezza, territorio, popolazione. Corso al College de France, 1977-1978. Milano: Feltrinelli.

Goldstein, J., Freud A. \& Solnit, A. J. (1979). Before the Best Interests of the Child. New York: The Free Press.

Howell, S. (2007). The Kinning of Foreigners. Transnational Adoption in a Global Perspective. New York: Bergham Books.

Hubinette, T. (2006). Comforting an Orphaned Nation: Representations of International Adoption and Adopted Koreans in Koreann Popular Culture. Seoul: Jimoondang Publisher.

Hubinette, T. (2004). A critique of intercountry adoption. In Dudley, W. (Eds.). Issues in Adoption. Current Controversies (pp. 66-71). Farmigton Hills: Greenhaven Press.

Krais, B. \& Gebauer, G. (2009). Habitus. Roma: Armando Editore.

Lovelock, K. (2000). Intercountry Adoption as a Migratory Practice. International Migration Review, 34, 907-949.

Modell, J. (1994). Kinship with Strangers. Adoption and Interpretation of Kinship in American Culture. Berkley: University of California Press.

Parker, R. (2008). Uprooted: The Shipment of Poor Children to Canada, 1867-1917. Bristol: Policy Press.

Selman, P. (2002). Intercountry Adoption in the New Millenium: The 'Quiet Migration' Rivisited. Population Research \& Policy Review, 21, 205-225.

Selman, P. (2006). Trends in Intercountry Adoption 1998-2004: Analysis of Data from 20 Receiving Countries. Journal of Population Research, 23, 183-204.

Selman, P. (2009). The rise and fall of intercountry adoption in 21th century. International Social Work, 52, 575-593.

Smolin, D.M. (2007). Child Laundering as Exploitation: Applying Anti-trafficking Norms to Intercountry Adoption Under the Coming Hague Regime. ExpressO. http://works.bepress.com/david_smolin/4. Viewed 28/2/2012.

Solstad, S.P. (2005). Intercountry Adoption: Global Gift or Global Trade? Master Thesis, Universitat Jaume I, Oslo.

Triseliotis, J. (2000). Intercountry adoption: global trade or global gift?. Adoption \& Fostering Journal, 24, 45-54.

Volkman, T. A. (2005). New Geographies of Kinship. In Volkman, T. (Eds.), Cultures of Transnational Adoption, (pp. 1-22). Durham:Duke University Press.

Westcott, K. (2010). Protecting Haiti's children from 'cowboy adoption'. BBCNews, 1 February 2010. http://news.bbc.co.uk/2/hi/ 8491981.stm. Viewed 23/12/2011.

Yngvesson, B. (2010). Belonging in an Adopted World. Chicago: University of Chicago Press.

Yngvesson B. (2002). Placing the Gift Child in Transnational Adoption. Law\&Society, 36, 227-243.

Yngvesson, B. \& Mahoney, M. A. (2007). As One Should, Ought and Want to Be: Belonging and Authenticity in Identity Narratives. Theory, Culture \& Society, 17, 77-110. 